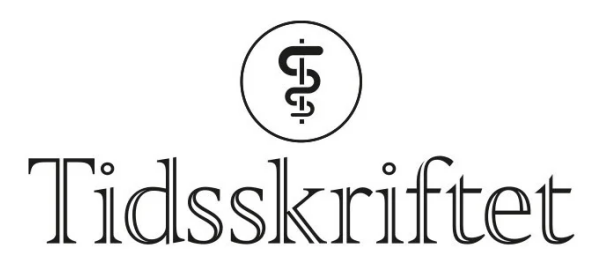

DEN NORSKE LEGEFORENING

\title{
Turnustjenesten er syk og trenger behandling
}

KOMMENTAR

\section{GRY MERETE OMLAND}

Gry Merete Omland (f. 1982) er stud.med. Ingen oppgitte interessekonflikter. Email: gry.omland@student.uib.no

\section{SIMONE FRIZELL REITER}

Det medisinske-odontologiske fakultet Universitetet i Bergen

Det er forhastet å forkaste en turnusordning som sikrer kvalitet og god fordeling av leger. Vi foreslår strengere språkkrav, kurs om kvalitetsarbeid, pasientsikkerhet og forhold som særpreger norsk medisin, innføring av depositum, karantene for kandidater som ikke møter opp, og styrking av Statens autorisasjonskontor for helsepersonell.

Kapasiteten i dagens turnusordning for leger er sprengt. Både Helsedirektoratet og Legeforeningen ønsker å avvikle dagens ordning og å innføre en søknadsbasert basistjeneste. Sentralstyret går inn for at en slik basistjeneste skal telle som første obligatoriske del av spesialistutdanningen, at medisinske kandidater (cand.med.) ikke har rett til basistjeneste, at stillingene ikke skal fordeles sentralt etter loddtrekning, slik som turnusstillinger blir i dag, og at autorisasjon som lege gis etter avlagt medisinsk embetseksamen (1). Det meste i dette forslaget er sammenfallende med Helsedirektoratets forslag fra $2010(\underline{1}, \underline{2})$. Hovedargumentet er kapasitetsproblemene i dagens turnustjeneste. Helsedepartementet har varslet ny høring.

\section{Rekrutteringen av leger til distriktene}

Turnustjenesten er viktig for å sikre rekrutteringen av leger til distriktene. Sentral fordeling av turnusplass gir distriktene mulighet til å presentere seg. Nesten en tredel av stillingene i allmennlegetjenesten i Finnmark var i 1997 enten vakante eller besatte av leger i korte 
vikariater. Etter at det ble opprettet veiledningsgrupper for turnuslegene, begynte antallet vakante stillinger å falle. I perioden 1999-2006 valgte dobbelt så mange som forventet Nord-Norge som arbeidssted etter å ha gjennomført turnustjeneste i Finnmark. Blant dem som var utdannet ved Universitetet i Oslo, valgte $36 \%$ videre jobb i fylket (3), mot forventet $7,5 \%(4)$.

Dette viser at turnustjenesten er et viktig virkemiddel for å sikre en god legefordeling. Alle blir ikke værende i distriktene etter endt turnus, men også de som ikke blir, får med seg kunnskap og forståelse for de utfordringer som finnes i distriktene. Dette tar de med seg videre i pasientrettet og administrativt arbeid.

Ordningen i Sverige med allmänntjänstgöringen (AT) likner på forslagene om basisstillinger (fra Legeforeningen) og nybegynnerstillinger (fra Helsedirektoratet). I 2008 ble 17 AT-stillinger i svenske utkantdistrikter ikke benyttet (2) , til tross for at gjennomsnittlig ventetid fra legeeksamen til AT-start var sju måneder (5). I 2010 var den gjennomsnittlige ventetiden 8,2 måneder, med store regionale forskjeller - fra 3,5 til 13,6 måneder. 82 \% oppga at de hadde jobbet som vikarer før de begynte sin AT-tjeneste (5). Dette underbygger bekymringen for at stillinger i distriktene kan bli vanskelige å besette og kan bli stående tomme fordi kandidater foretrekker å gå i vikariater mens de venter på «ønskestillingen» i urbane strøk.

Danmark gikk i 1984 vekk fra en søknadsbasert ordning og over til en trekningsbasert ordning. Begrunnelsen var lange ventelister i universitetsnære områder og ledige stillinger i distriktene. Danske helsemyndigheter påpekte i 2004 faremomentene ved en eventuell gjeninnføring av søknadsbasert tjeneste ( $\underline{6})$.

\section{Kvalitet og pasientsikkerhet}

Ifølge EØS-reglene kan ikke Norge lenger kreve veiledet tjeneste for nyutdannede kandidater med legeautorisasjon i EØS-land. Dette brukes av Legeforeningen som argument for å fjerne turnusordningen og innføre basisstillinger (1). Torunn Janbu skriver at «den eneste måten vi da kan sikre at disse legene får en god start på utdanningen/arbeidslivet, er å flytte turnus inn som en basistjeneste i begynnelsen av spesialistutdannelsen» (1). Kandidater med legeautorisasjon fra et EØS-land vil ha rett på norsk legeautorisasjon uten ytterligere plikttjeneste. Legeforeningen går inn for å sette kandidater utdannet i Norge i samme situasjon.

Situasjonen i Sverige, hvor kandidater blir gående i vikariater i påvente av en attraktiv ATstilling, kan bli fremtiden også i Norge hvis en søknadsbasert ordning innføres. Selv om svenske leger får legeautorisasjon først etter fullført AT-tjeneste (므), fikk kun $37 \%$ av dem som gikk i vikariater, personlig veiledning mens de ventet på sin AT-tjeneste (5). Norske kandidater vil med den nye ordningen ha full autorisasjon etter medisinsk embetseksamen, så hvilken veiledning vil de få når de går i vikariater?

Norske studieplaner er tilpasset veiledet tjeneste i turnustiden - ikke til selvstendig legearbeid etter embetseksamen. Gjennom studiet får studentene stadig høre at «dette lærer dere i turnus». En studie fra 2003 viste at etter endt turnustjeneste i distrikt rapporterte alle turnusleger et signifikant forbedret ferdighetsnivå i praktiske prosedyrer. Turnustjenesten jevnet ut forskjeller mellom kandidater og læresteder. De som var svakest i utgangspunktet, forbedret seg mest (7.), noe som taler mot at de faglig svakeste skal vente lengst på tjeneste. Turnustjenesten er samfunnets mulighet til å kvalitetssikre nyutdannede leger før selvstendig legearbeid.

\section{Hva man kan gjøre?}


EU-direktivet om fri flyt av arbeidskraft gjør at vi ikke kan foretrekke norske søkere fremfor utenlandske søkere til turnustjenesten - så lenge turnustjenesten er definert som arbeid. Definerer man tjenesten som en del av utdanningen ved de norske medisinske fakultetene, diskriminerer man automatisk norske studenter som studerer i utlandet. Dersom kandidater med utenlandsk grunnutdanning, uavhengig av statsborgerskap, ikke sikres veiledet tjeneste, er det pasientene som kommer til å tape mest.

Det uteksamineres rundt 580 medisinske kandidater fra norske universiteter årlig, og det er noe over 900 turnusplasser $(\underline{1}, \underline{2})$. Rundt 400 kandidater med norsk statsborgerskap

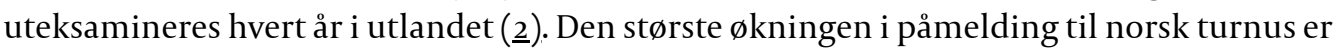
i dag fra en annen gruppe: utenlandske statsborgere med utenlandsk grunnutdanning. Alle studenter som uteksamineres fra universiteter i utlandet mangler kunnskap i norsk trygdemedisin, rettsmedisin, reseptlære og samfunnsmedisin. En del utenlandske statsborgere har i tillegg omfattende språkproblemer (므).

Utfordringen er altså at man har for mange kandidater som tilfredsstiller kravene for å kunne melde seg på norsk turnustjeneste. Ved å sette høyere krav til både språkkunnskaper og innsikt i norske medisinske fag, kan man både løse kapasitetsproblemet og integrere kunnskap om kvalitetsutvikling og pasientsikkerhet bedre i grunnutdanningen. Ifølge EU-direktivet om gjensidig godkjenning av yrkeskvalifikasjoner kan man ikke stille slike krav for å gi norsk autorisasjon, men de kan forhåpentligvis - stilles for påmelding til norsk turnustjeneste. Det er ikke lenger lov å kreve at nyutdannede leger fra et EU/EØS-land skal gjennomføre veiledet tjeneste. Dette kan tenkes løst ved at krav tilsvarende dagens veiledet tjeneste blir en del av alle spesialiteter, og at gjennomført norsk turnustjeneste er en mulighet til å avtjene slik tjeneste. De fleste norske kandidater som er uteksaminert i utlandet ønsker for øvrig å avtjene norsk turnustjeneste $(\underline{2}, \underline{8})$.

\section{Språkkravene må skjerpes}

Helsedirektoratet har avvist Legeforeningens forslag om å heve språkkravet (11). Med hvilken begrunnelse?

Hele 18 turnusleger fikk i 2008 underkjent sin tjeneste, i stor grad pga. manglende språkkunnskaper og generelle kommunikasjonsproblemer (므). Dagens språkkrav er «bestått» på den såkalte Bergenstesten eller bestått norskeksamen trinn III ved norsk universitet eller høyskole med karakter «B» både muntlig og skriftlig (9.). Det europeiske rammeverket for språk definerer seks ulike nivåer for vurdering av språkkunnskaper (므).

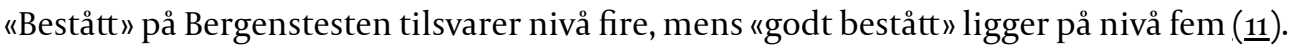

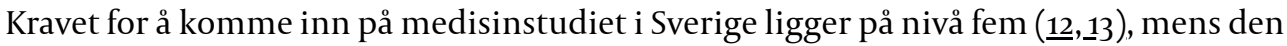
standardiserte testen for opptak i Tyskland ligger mellom nivå fire og fem (14.)-(16). Dette betyr i praksis at det er lavere språkkrav for å praktisere som turnuslege i Norge enn det er for å få begynne å studere medisin i Sverige og Tyskland.

\section{Kurs om norske forhold}

Innføring av kurs om norsk rettsmedisin, trygdemedisin, reseptlære og samfunnsmedisin og krav om at kurset må være bestått før påmelding til turnustjenesten, vil sikre et minimum av innsikt i norsk helsevesen.

Et slikt kurs må være felles for alle og dekkes innenfor rammene av studieplanene ved norske medisinske fakulteter. Det må i tillegg legges til rette for at studenter ved medisinske fakulteter i utlandet kan ta kurset i løpet av en av de siste somrene før avslutning av studiet. Et slikt kurs vil gi alle kandidater viktige basisferdigheter og sørge for 
at veiledning i større grad kan brukes til medisinskfaglige spørsmål. Man kan ytterligere heve kvaliteten og bedre pasientsikkerheten dersom man i kurset - og i studieplanene - tar med kvalitetsarbeid og pasientsikkerhet.

Slik kan man bevare turnustjenesten samtidig som man gir utdanningen et skikkelig kvalitetsløft. Ved Universitetet i Oslo er kunnskapshåndtering, ledelse og kvalitetsforbedring (KLoK) allerede integrert i studiet (17.), et opplegg som er i tråd med Helsedirektoratets nasjonale satsing for kvalitetsforbedring i sosial- og helsetjenesten (묘), Norsk medisinstudentforenings krav om felles nasjonalt kjernepensum (19.) og

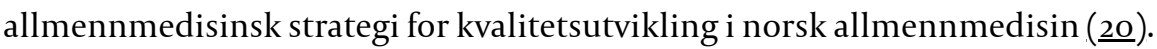

\section{Andre tiltak}

Statens autorisasjonskontor for helsepersonell (SAFH) har i dag kun fire årsverk som benyttes til arbeid med turnustjenesten (2). Turnusordningen må altså sies å være underadministrert. Autorisasjonskontoret fordeler plassene under valget, behandler alle søknader om påmelding og særplass, arrangerer suppleringsvalg og holder kontakt med studentene, helseforetakene og kommunene. I tillegg behandler kontoret alle klager i forbindelse med underkjenning av turnustjenesten.

Mange kandidater møter ikke opp ved start av turnus (므). Dette er et stort problem. En innføring av depositum for påmelding til turnustrekning vil kunne luke ut påmeldinger fra kandidater som ikke har til hensikt å avlegge turnustjeneste. Helsedirektoratet åpnet i 2008 for innføring av depositum (므). Kandidater som trekker seg eller ikke møter til tildelt turnusplass uten gyldig grunn, bør i tillegg til å miste sitt depositum også bli utestengt fra turnustrekning en viss tid.

Medisinske kandidater som går i vikariat for turnusleger, bør få disse godkjent som tellende tjeneste. Disse stillingene har allerede nødvendige ressurser i form av veiledning og oppfølgning knyttet til seg.

\section{Det er ingen skam å snu}

Norge må ikke velge en søknadsbasert ordning som Danmark avskaffet og ikke vil gjeninnføre, og som fungerer dårlig i Sverige. Muligheten til å kvalitetssikre nyutdannede leger forsvinner hvis man innfører legeautorisasjon rett etter medisinsk embetseksamen. Det finnes tiltak som kan løse kapasitetsproblemene. Vårt forslag til tiltak er strengere språkkrav, kurs i kvalitet/pasientsikkerhet og det særegne ved norsk medisinsk praksis, depositum, karantene og en styrket administrasjon av turnusordningen sentralt.

Takk til Janecke Thesen og Helen Brandstorp for veiledning og innspill.

LITTERATUR

1. Braaten KE. Ny søknadsbasert turnustjeneste. http://legeforeningen.no/id/168534.o. (30.3.2011).

2. Nybyrjarstilling for legar - praktisk og pedagogisk oppfølging av nyutdanna leger. Oslo: Helsedirektoratet, 2010.

3. Straume K, Shaw DMP. Internship at the ends of the earth - a way to recruit physicians? Rural Remote Health 2010; 10: 1366.

4. Alexandersen $\emptyset$, Jørgensen E, Østerås J et al. Medisinerutdanningen i Troms $\emptyset$ - sikrer den legerekrutteringen til Nord-Norge? Tidsskr Nor Lægeforen 2004; 124: 2107-9.

5. SYLF: s AT-ranking 2010. Stockholm: Sveriges yngre läkares förening, 2010.

www.nsdm.no/filarkiv/File/Eksterne_rapporter/AT-rankingen_202010_1__1_.pdf(25.4.2011).

6. Turnustjenesten for leger - en helhetlig gjennomgang. Oslo: Sosial- og helsedirektoratet, 2008. 
7. Falck G, Brattebø G, Brinchmann-Hansen Å et al. Selvrapportert ferdighetsnivå i praktiske prosedyrer etter turnustjeneste i distrikt. Tidsskr Nor Lægeforen 2003; 123: 2265-7.

8. Slipper turnus via smutthull. Dagens Medisin.

www.dagensmedisin.no/nyheter/2006/04/27/slipper-turnus-via-smutthul/index.xml (22.3.2011).

9. Turnustjeneste for leger. Oslo: Statens autorisasjonskontor for helsepersonell. www.safh.no/yrkesgrupper/legeturnus.html (21.3.2011).

10. Det felles europeiske rammeverket for språk. Oslo: Utdanningsdirektoratet, 2007.

11. Test i norsk - høyere nivå, skriftlig. Oslo: Folkeuniversitetet, 2011. www.fu.no/default.asp? avd=231\&nyh=5389 (20.3.2011).

12. Test i svenska för universitets och högskolestudier, tisus. Om tisus. Stockholm: Stockholms universitet, 2011. www.nordiska.su.se/pub/jsp/polopoly.jsp?d=1668 (21.3.2011).

13. Vanliga frågor. Göteborg: Swedex: Swedish examinations. www.folkuniversitetet.se/Las-mer-omsprak/Sprakexamina/Swedex/FAQ/\#5 (21.3.2011).

14. Deutschtests fur die Uni. Studieren in Deutschland. www.study-in.de/de/studium/deutschesprache/deutsch-lernen--13785(21.3.2011).

15. Deutschkentnisse. Heidelberg: Universität Heidelberg. www.uniheidelberg.de/studium/interesse/int_bewerbung/deutschk.html (21.3.2011).

16. Beschreibung der TestDaF Niveaustufen TDN. TestDaf-Institut. www.testdaf.de/teilnehmer/tninfo_nivea.php (27.3.2011).

17. Kunnskapshåndtering, ledelse og kvalitetsforbedring. Oslo: Universitetet i Oslo. www.med.uio.no/studier/medisin/fagsider/klok/ (27.3.2011).

18. ... og bedre skal det bli! Nasjonal strategi for kvalitetsforbedring i sosial- og helsetjenesten. Oslo: Sosial- og helsedirektoratet, 2005.

19. «Core curriculum»/Standardiserte læringsmål. Oslo: Norsk medisinstudentforening. www.medisinstudent.no/id/47183.(7·4.2011).

20. Trygg hos fastlegen og på legevakta. Allmennmedisinsk kvalitetsutvalg www.legeforeningen.no/id/151920 (7.4.2011).

Publisert: 20. mai 2011. Tidsskr Nor Legeforen. DOI: 10.4045/tidsskr.11.0488

Mottatt 13.4. 2011 og godkjent 28.4. 2011. Medisinsk redaktør Petter Gjersvik.

(C) Tidsskrift for Den norske legeforening 2023. Lastet ned fra tidsskriftet.no 26. april 2023. 